13. Zimakoff J, Pontoppidan B, Larsen SO, et al. Management of urinary bladder function in Danish hospitals, nursing homes, and home care. J Hosp Infect 1993;24:183-199.

14. Katz S, Downs TD, Cash HR, Grotz RC. Progress in development of the index of ADL. Gerontologist 1970;10:20-30.

15. The International Continence Society Committee on Standardization of Terminology. Scand J Urol Nephrol 1988; (suppl) 114:5-19.

16. Centers for Disease Control. Outline for Surveillance and Control of Nosocomial Infections. App.II. Atlanta, GA: US Department of Health, Education and Welfare; 1972.

17. Garner JS, Jarvis WR, Emori T, et al. CDC definitions for nosocomial infections, 1988. Am J Infect Control 1988;16:128-140.

18. Cox DR, Snell EJ. Analysis of Binary Data. 2nd ed. London, England: Chapman and Hall; 1989.

19. Magaziner J, Tenney JH, Deforge B, et al. Prevalence and characteristics of nursing home-acquired infections in the aged. $J$ Am Geriatr Soc 1991;39:1071-1078.

20. Warren JW, Steinberg L, Hebel JH, et al. The prevalence of urethral catheterization in Maryland nursing homes. Arch Intern Med 1989;149:1535-1537.

21. Lewis SM. The effect of surveillance definitions on nosocomial urinary tract infection rates in a rehabilitation hospital. Infect Control Hosp Epidemiol 1995;16:43-48.

22. Warren JW, Palumbo FB, Fitterman L, et al. Incidence and characteristics of antibiotic use in aged nursing home patients. J Am Geriatr Soc 1991;39:963-972.
23. Zimakoff J, Pontoppidan B, Larsen SO, et al. Quality Assessments of Efforts to Prevent Nosocomial Urinary Tract Infections in Denmark, 1980-1990. Report to the National Board of Health. Statens Serumistitut, Copenhagen, Denmark, 1992:1-59.

24. Hebel JR, Warren JW. The use of urethral, condom, and suprapubic catheters in aged nursing home patients. J Am Geriatr Soc 1990;38:777-784

25. Fierer J, Ekstrom M. An outbreak of Providencia stuartii urinary tract infections. JAMA 1981;245:1553-1555.

26. Hirsh DD, Fanstein V, Musher DM. Do condom catheter collecting systems cause urinary tract infection? JAMA 1979;242:340-341.

27. Ouslander JG, Greengold B, Chen S. External catheter use and urinary tract infections among incontinent male nursing home patients. J Am Geriatr Soc 1987;35:1063-1070.

28. Brandberg Å, Seeberg S, Bergström G, et al. Reducing the number of nosocomial gram-negative strains by using high absorbing pads as an alternative to indwelling catheters in longterm care—a preliminary study. J Hosp Infect 1980;1:245-250.

29. Seeberg S, Brandberg A, Bergström G, et al. The effect on bacteriuria of removal of indwelling catheters and treatment with co-trimoxazole. J Hosp Infect 1982;3:159-164.

30. Nordqvist P, Ekelund P, Edouard L, et al. Catheter-free geriatric care. Routines and consequences for clinical infection, care and economy. J Hosp Infect 1984;5:298-304.

\title{
Risk of HIV Transmission by Screened Blood
}

\section{by Gina Pugliese, RN, MS Medical News Editor}

Published results of a study by CDC researchers recently estimated that the current risk of HIV transmission caused by transfusion is from one in 450,000 to one in 660,000 in the United States. These estimates were made on the basis of the window period associated with the use of current, sensitive enzyme immunosorbent assays, and recent data on HIV incidence among blood donors. In the United States, transmission of HIV by blood transfusion occurs almost exclusively when a recently infected blood donor is infectious but before antibodies to HIV become detectable (during the window period).

The researchers analyzed demographic and laboratory data on more than 4.1 million blood donations obtained in 1992 and 1993 in 19 regions served by the American National Red Cross, as well as the results of HIV antibody tests of 4.9 million donations obtained in an additional 23 regions. Based on this analysis, it was estimated that one donation in every 360,000 was made during the window period. In addition, it is estimated that one in 2,600,000 donations was HIV seropositive, but was not identified as such because of an error in the laboratory. It was estimated that $15 \%$ to $42 \%$ of window-period donations were discarded because they were seropositive on laboratory tests other than the HIV-antibody test. When these results were extrapolated to include the additional 23 Red Cross service regions, there was a risk of one case of HIV transmission for every 450,000 to 660,000 donations of screened blood.
The estimates in this study were based on the average 25-day window period that exists given contemporary recombinant, protein-based enzyme immunosorbent assays. Earlier studies based on estimated window periods of 56 days and 45 days with whole-virus-lysate, reported risks of HIV transmission of 1 in 153,000 and one in 225,000 donations, respectively. The authors conclude that the estimated risk of transmitting HIV by the transfusion of screened blood is very small and nearly one half of that estimated previously, primarily because the sensitivity of enzyme immunosorbent assays has been improved.

FROM: Lackritz EM, Satten GA, Aberle-Grasse J, et. al. Estimated risk of transmission of HIV by screened blood in the United States $N$ Engl J Med 1995;333:1721-1725. 